\title{
Study of chromosomal abnormalities in Channa punctatus exposed to fenvalerate
}

\author{
Kamal Kumar Saxena* and Renu Chaudhari \\ Pest and Parasite Research Laboratory, Department of Zoology, Bareilly College, Bareilly-243005(U.P.), INDIA \\ *Corresponding author. E-mail: drkama106@yahoo.co.in
}

\begin{abstract}
The chromosomal aberration test in kidney cells of Channa punctatus was conducted to study the genotoxic effect of synthetic pyrethroid fenvalerate, Different chromosomal abnormalities were seen and their frequency was recoded in metaphase spreads obtained from fishes exposed to three sub lethal concentrations $(0.0625,0.0314$ and $0.0157 \mathrm{ppm})$ of this compound. The exposure to fenvalerate caused various structural abnormalities in chromosomes such as chromatid break, fragment, gap, chromatid separation, deletion and ring type chromosomes. Results obtained in present investigations clearly indicate that fenvalerate acts as a genotoxic agent in Channa punctatus.
\end{abstract}

Keywords: Fenvalerate, Chromosomal aberration, Genotoxic effect, Channa punctatus

\section{INTRODUCTION}

Pesticides are being used very commonly throughout the world for various purposes. These are main harmful pollutants among the chemicals released by man into the environment. In an ideal situation, a pesticide should fall exactly on the target and get degraded completely into harmless compounds. As per the estimate of Piemental and Leviton (1986) only less than $1 \%$ of the pesticides used reaches target and the remaining part spreads in the surroundings which in turn affects the non target organisms and cause pollution in the environment. Fish provides a suitable model for monitoring aquatic genotoxicity because of their ability to metabolize xenobiotics and accumulate pollutants (Grisolia and Cordeiro, 2000). Fishes can also respond to mutagens at low concentration of toxicants in a manner similar to higher vertebrates (Al-Sabti and Metcalfe, 1995).

The changes caused by genotoxins in the genetic material can be detected in fish at specific level by using various genotoxic assay. In fish kidney chromosomes the chromosome aberration test (CAT) is most suitable to study the genotoxic effect of pesticides. Synthetic pyrethroids are reported (Saxena and Seth, 2002; Seth and Saxena, 2003, Sirohi and Saxena, 2006 and Saxena and Sirohi, 2007) to be highly toxic to fish because of these compounds are strongly absorbed by the gills even at very low concentration in water due to their high lipophilicity. These compounds possess moderate mammalian toxicity but they are extremely toxic to fish and aquatic invertebrates (Eisler, 1992).

The study of genotoxic effect of pesticides and other pollutants in fishes is very important. Some workers (Rishi and Grewal, 1995; Arockia-Rita and Selvanayagam, 1998;
Chauhan et al., 2000; Devi et al., 2001; Aboul, 2002; Poli et al., 2003; Lioi et al., 2004; Saxena and Rana, 2005 and Ali et al., 2008) have reported genotoxic effects of some pesticides and other pollutants on mammals and fishes. In present study an attempt has been made to study the effect of fenvalerate on chromosomes of Channa punctatus.

\section{MATERIALS AND METHODS}

The common fresh water fish Channa punctatus were collected from the fresh water resources of Bareilly and adjoining places and acclimatized to laboratory conditions for few days in untreated soft water. After acclimation the fish were divided in to experimental and control groups. The experimental group fishes were exposed to different concentrations of fenvalerate $(0.0625$, 0.0314 and $0.0157 \mathrm{ppm})$.

Chromosomal preparations were made according to the method of Ojima (1982), Nagpure and Barat (1997) and Asano et al. (1998). After exposure to fenvalerate, the injection of $0.05 \%$ Colchicine ( $1 \mathrm{ml}$ per $100 \mathrm{gm}$ body wt.) was given to the fishes and they were left for $2 \mathrm{hrs}$. After this time duration the kidneys were excised from the treated fishes and were immediately transferred to separate Petri dishes containing freshly prepared $0.56 \%$ $\mathrm{KCl}$ (hypotonic solution). After processing the tissues the suspension was prepared and centrifuged.

After discarding the supernatant, remaining part was fixed with methanol acetic acid fixative. These slides were prepared by dropping method and after staining with Giemsa stain cells were covered with D.P.X. The chromosomes were observed by using 100x oil immersion microscope and their photographs were taken. 
Table 1. Frequency of chromosomal aberrations induced by fenvalerate in kidney cells of Channa punctatus.

\begin{tabular}{|c|c|c|c|c|c|}
\hline $\begin{array}{l}\text { Concentration of } \\
\text { fenvalerate (in ppm) }\end{array}$ & $\begin{array}{l}\text { Exposure } \\
\text { period } \\
\text { (in hours) }\end{array}$ & $\begin{array}{l}\text { No. of fishes } \\
\text { dissected }\end{array}$ & $\begin{array}{l}\text { No. of metaphase } \\
\text { spreads studied }\end{array}$ & $\begin{array}{l}\text { No. of metaphase } \\
\text { spreads with } \\
\text { abnormalities }\end{array}$ & $\begin{array}{l}\text { \% of metaphase } \\
\text { spreads with } \\
\text { abnormalities }\end{array}$ \\
\hline \multirow{7}{*}{$\begin{array}{c}0.0000 \\
\text { (Control) }\end{array}$} & 0 & 5 & 50 & 0 & 0 \\
\hline & 24 & 5 & 50 & 0 & 0 \\
\hline & 48 & 5 & 50 & 1 & 2 \\
\hline & 72 & 5 & 50 & 2 & 4 \\
\hline & 96 & 5 & 50 & 1 & 2 \\
\hline & 120 & 5 & 50 & 2 & 4 \\
\hline & 144 & 5 & 50 & 2 & 4 \\
\hline \multirow{6}{*}{0.0157} & 24 & 5 & 50 & 1 & 2 \\
\hline & 48 & 5 & 50 & 7 & 14 \\
\hline & 72 & 5 & 50 & 10 & 20 \\
\hline & 96 & 5 & 50 & 16 & 32 \\
\hline & 120 & 5 & 50 & 13 & 26 \\
\hline & 144 & 5 & 50 & 6 & 12 \\
\hline \multirow{6}{*}{0.0314} & 24 & 5 & 50 & 3 & 6 \\
\hline & 48 & 5 & 50 & 10 & 20 \\
\hline & 72 & 5 & 50 & 19 & 38 \\
\hline & 96 & 5 & 50 & 23 & 46 \\
\hline & 120 & 5 & 50 & 17 & 34 \\
\hline & 144 & 5 & 50 & 11 & 22 \\
\hline \multirow{6}{*}{0.0625} & 24 & 5 & 50 & 6 & 12 \\
\hline & 48 & 5 & 50 & 11 & 22 \\
\hline & 72 & 5 & 50 & 29 & 58 \\
\hline & 96 & 5 & 50 & 37 & 74 \\
\hline & 120 & 5 & 50 & 21 & 42 \\
\hline & 144 & 5 & 50 & 19 & 38 \\
\hline
\end{tabular}

\section{RESULTS AND DISCUSSION}

In the present investigations changes in kidney cells of Channa punctatus have been observed due to exposure to sub lethal concentrations of fenvalerate. The change in chromosomal structures directly affects the genetic material of the animals and by examining the metaphase structure of chromosomes after exposure to pesticides like fenvalerate, the clastogenic properties of the pesticide can be detected (Ali et al., 2009). In Channa punctatus 32 chromosomes were observed in normal diploid cells in both sexes. No sex chromosomes were observed in this fish species. These observations are in agreement with the earlier data available (Rishi and Haobam, 1990 and Rishi and Grewal, 1995, Saxena and Rana, 2008). In present study prominent changes in the structure of chromosomes, such as decrease in length, increase in breadth and over all compression in size was observed.
Some important chromosomal aberrations were chromatid breaks, fragments, gaps, chromatid separation, acentric fragments, deletion and ring type chromosomes.

The data obtained indicate that the frequencies of chromosomal abnormalities were higher during the initial period of exposure and there after declined. However, they were still higher than the frequencies in control samples (Manna and Mukherjee, 1986). It was also recorded that as the exposure period increased, the percentage of chromosomal abnormalities also increased. When the fishes were exposed for 96 hours, the metaphase spreads had only two types of abnormalities. Chromosomal breaks were observed more than any other type chromosomal abnormalities when fish Channa punctatus were exposed to $144 \mathrm{hrs}$. (Mathew and Jahageerdar, 1999) have also reported similar observations in Channa punctatus exposed to heavy metals. 


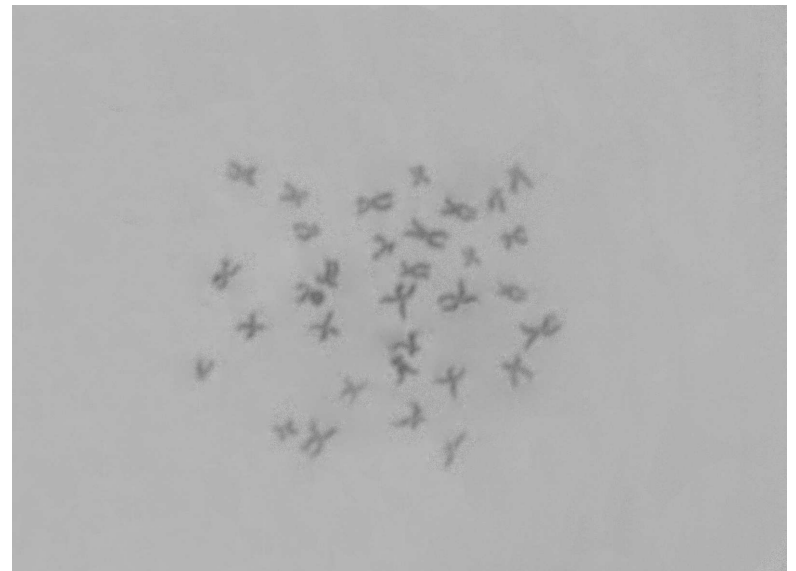

Fig. 1. Metaphase spread of kidney cell of control group fish.

Acute and sublethal toxicity are the important parameters for the evaluation of pesticidal activity. Mortality depends upon the concentration and duration of exposure. Data obtained in present studies indicate that fenvalerate is highly toxic to Channa punctatus, as it caused mortality at the $0.10 \mathrm{ppm}$. In the present studies, LC50 of fenvalerate for Channa punctatus was also determined since the study of sublethal toxicity of pesticides is more important than the acute toxicity (Alderic, 1967) because it gives an idea about the mode of action of the compound inside the body of fish.

During fenvalerate treatment, Channa punctatus showed several changes in their behaviour. This behaviour response varied in accordance with the concentration of fenvalerate. At higher concentrations they exhibited erratic swimming. They often lost their balance and dashed against the wall of aquaria and even tried to escape out. The fishes often came to the surface of water to gulp atmospheric air, which may be to avoid the toxic environment. Opercular activity was increased after exposure to fenvalerate. In the present investigations the colour of fish became pale and this change was also dependent on the concentration of fenvalerate. These findings are in agreement with Seth and Saxena (2003). The change in chromosomal structures directly affects the genetic material of the animals. The DNA repair is reported (Matsumura, 1985) to be slower in fishes than mammals therefore, these changes appear to be useful in detecting genotoxicity caused by aquatic pollutants in fishes. By examining the metaphase structure of chromosomes after exposure to pesticides like fenvalerate, the clastogenic properties of the pesticide can be detected. It was observed that chromosomes in exposed fishes were reduced in length in comparison to the chromosomes of control fishes. Aquatic organisms are susceptible to the chemicals present in their surroundings and if these chemicals cause DNA damage, it may result into a variety of abnormalities like reduced

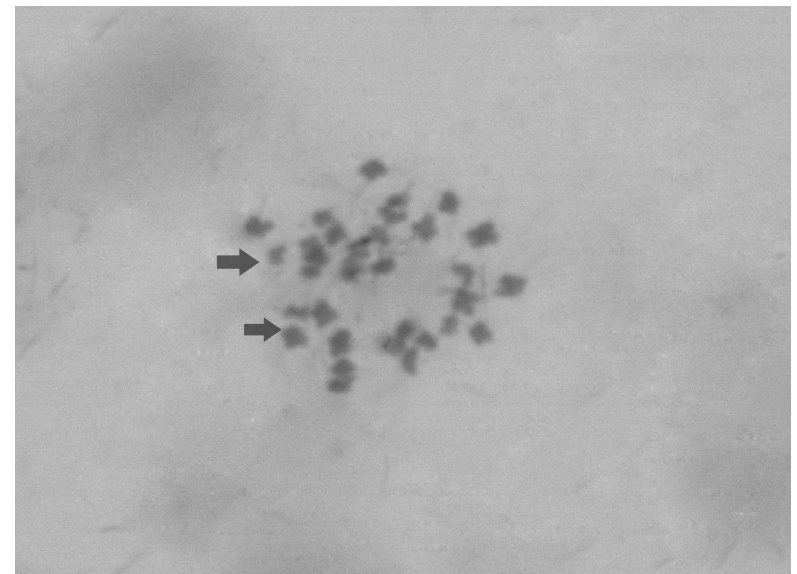

Fig. 2. Metaphase spread of kidney cell of fish exposed to fenvalerate

growth, abnormal development and age of adult and larval stages. Chromosomal mutations may cause carcinogenesis and the development of various syndromes (Bond and Rossbacher, 1993).

The percentage of metaphase spreads with abnormalities was also very high i.e. more than $70 \%$ at all the concentrations used. The abnormalities were significant at the level of Pd"0.01. More than three types of aberrations were also observed in a single metaphase spread in several cases. The abnormalities depended upon both exposure period and dose level of fenvalerate. The results presented in this study clearly show that exposure to fenvalerate, even at very low concentrations cause chromosomal abnormalities, which are directly associated with DNA damage. It shows a high level of genotoxic potential of fenvalerate for this fish species. This may affect over all fish health and in turn may also affect other animals including human beings which are consuming the fish as food.

\section{REFERENCES}

Aboul, Ela. E.I. (2002). Genotoxic effect of rifampicin on the mouse. Bull. Mat. Res. Centre, 27: 385-395.

Al-Sabti, K. and Metcalfe, C.D. (1995). Fish micronuclei for assessing genotoxicity in water. Mutat. Res., 343: 121-135.

Alderic, D.F. (1967). Detection and measurement of water pollution biological assay. Canadian Fisheries, 9: 33-39.

Ali, D., Nagpure, N.S., Kumar, S., Kumar, R., Kushwaha, B. and Lakra, W.S. (2009) Assessment of genotoxic and mutagenic effects of chlorpyrifos in freshwater fish Channa punctatus (Bloch) using micronucleus assay and alkaline single-cell gel electrophoresis. Food Chem. Toxicol., 47(3):650-656.

Ali, F.K., El-Shehawi, A.M. and Seehy, M.A. (2008). Micronuleus test in fish genome: a sensitive monitor for aquatic pollution. African J. Biotech., 7(5): 606-612.

Arokia-Rita, J.J. and Selvanayagam, M. (1998). Genotoxic effect of fenvalerate on the chromosomes of fish Oreochrochromis mossambicus (Peter). Poll. Res., 17(2): 119-122. 
Asano, Y.F.N., Sifuni, T. and Ojima, Y. (1998). Development of genotoxic assay systems that use aquatic organisms. Mautat. Res., 399: 125-133.

Bond, G.G. and Rossbacher, R. (1993). A review of potential human carcinogenecity of the chlorophenoxy herbicides. MCPA, MCPP and 2, 4-DP. Br. J. Ind. Med., 50:340-348.

Chauhan, L.K.S., Pant, N., Gupta, S.K. and Srivastava, S.P. (2000). Induction of chromosomal aberrations, micronucleus formation and sperm abnormalities in mouse following of carbofuran exposure. Mut. Res., 465: 123-129.

Devi, K.D.; Rozati, R.; Banu, B.S.; Jamil, K. and Grover, P. (2001). In vivo genotoxic effect of potassium dichromate in mice leukocytes using comet assay. Food Chem. Toxicol., 39: 859-865.

Eisler, R. (1992). Fenvalerate hazards to fish, wildlife and invertebrates. A synoptic review. Biological report fish and wildlife service. US Department of the interior. $2.111+43 \mathrm{pp}$. Contaminant Hazard Reviews, Report. 24.

Grisolia C.K. and Cordeiro CMT (2000). Variability in micronucleus induction with different mutagens applied to several species of fish. Genetics and Molecular Biology, 23: 235-239.

Lioi, M.B.; Santoro, A.; Barbieri, R., Salzano, S. and Ursine, M.V. (2004). Ochratoxin A and Zearalenone : a comperative study on genotoxic effects and cell death induced in bovine lymphocyte, Mutation Res., 1: 19-27.

Manna, G.K. and Mukherjee, P.K. (1986). Effect of organophosphate insecticide melathion on chromosome, cell division and total muscle proteins of the cichlid fish Tilapia. In Pers. Cytol. and Genet. (Eds. G.K. Manna and U. Sinha) 5: 225-235.

Mathew, A., N.P. and Jahageerdar, S. (1999). Effect of heavy metal on the karyotype of Channa punctatus. Indian J.Fish, 46(2): 167-172.

Matsumura, F. (1985). In: Toxicology of insecticides, 2nd ed. Plenum Press, New York

Nagpure, N.S. and Barat, A. (1997). A simplified method of fish chromosome preparation by in vitro colchicine treatment. Ind. J.Exp. Biol., 35:915-916.
Ojima, Y. (1982). Method in fish cytogenetics Nucleus. 25: 1-7. Pimental, D. and Levitan, L. (1986). Pesticides-Amounts applied and amounts reaching pests. Biosciences. 36: 86-91.

Poli, P., Mello, M.A., de B Guschini, A.; Castro, V.L.S.S.; de Restivo, F.M., Rossi, C., Zocchi, T.M.A.D., de Mello, M.A. and de Castro V.L.S.S. (2003). Evaluation of the genotoxicity induced by fungicide fenarimol in mammalian and plant cells by use of single cell gel electrophoresis assay, Mutation Res. 540: 57-66.

Rishi, K.K. and Haobam, M.S. (1990). A chromosomal study on four species of snake haeds (Ophicoephalidae, Pisces) with comments on their Karyotype evolution. Caryologia, 43: 163-163.

Rishi, K.K. and Grewal, S.. (1995). Chromosome aberration test for the insecticide, dichlorvos, of fish chromosomes. Mutat. Res., 344: 1-4.

Saxena, K.K. and Rana, R. (2005). Genotoxic effect of cypermethrin in a fresh water fish Channa punctatus. Proceedings of International Transfer of Technology Initiative Workshop on Parasitology and Genotoxicity in Sustainable Aquaculture, Allahabad: 26.

Saxena, K.K. and Rana, R. (2008). Genotoxicity of permethrin in Channa punctatus by using chromosomal aberration test. Proceedings of 78th Annual Session and Symp. Nat. Acad. Sci., India. 41.

Saxena, K.K. and Seth, N. (2002). Toxic effect of cypermethrin on certain hematological aspects of fresh water fish Channa punctatus. Bull. Environ. Contam. Toxicol., 64: 364-369.

Saxena, K.K. and Sirohi, V. (2007). Effect of ë-cyhalothrin on the activities of trypsin and lipase in fresh water fish Channa punctatus. J. Fish. Aquatic Sci., 2(2): 168-172.

Seth, N. and Saxena, K.K. (2003). Haematological responces in a fresh water fish Channa punctatus to experimental fenvalerate poisoning. Bull. Environ. Contam. Toxicol., 71: 1192-1199.

Sirohi, V. and Saxena, K.K. (2006). Toxic effect of ë-cyhalothrin on biochemical contents of fresh water fish Channa punctatus. J. Fisheries Aquatic Sci., 1(2): 112-116. 